\title{
Jimmy Carter and the Sale of the AWACS to Iran in 1977
}

\author{
Stephen McGlinchey and Robert W. Murray
}

Accepted version: Forthcoming in Diplomacy and Statecraft, August 2017

\section{Introduction}

Jimmy Carter's experiences with Iran during his one term in office between 1977 and 1981 form a major component of his administration's legacy. It was an eventful period in which the administration was criticised for slow and indecisive reactions to the Shah's domestic decline in 1978 and the Islamic revolution that followed in 1979 . When adding the Iran hostage crisis and the debate over systematic failures of US intelligence regarding the loss of Iran, these stand-out issues have absorbed the bulk of analysis on Carter and Iran. ${ }^{1}$ Yet, an episode that remains underexplored is the implications of Carter's decision to sell Iran a fleet of highly advanced AWACS aircraft in 1977 as part of a \$5.7 billion dollar arms package including 160 F-16 fighter jets.

As an autocrat who was supressing political opposition in Iran, it seems surprising that the Shah was able to win support from the Carter administration for a major arms sale. It appeared that as 1977 dawned, the politics of a new president and the gathering momentum of a resurgent Congress, keen to introduce moderation in arms sales which had destabilised the Middle East, might make multi-billion dollar arms sales into unstable regions a thing of the past. After all, Jimmy Carter triumphed in the presidential election of November 1976 partially on a popular platform of arms control and the introduction of human rights considerations into U.S. foreign policy. Carter's transition from that idealistic candidate to the president who agreed a record breaking - and highly contentious - arms deal with the Shah is, therefore, outwardly confusing. Yet, when examining the entrenched policy path that Carter inherited regarding arming Iran and the larger needs of Cold War containment the logic of Carter's decisions to essentially betray his own campaigning policies becomes clear.

\footnotetext{
${ }^{1}$ For a representative example see: David Farber, Taken Hostage: The Iran Hostage Crisis and America's First Encounter With Radical Islam (Princeton: Princeton University Press, 2006); David Patrick Houghton, US Foreign Policy and the Iran Hostage Crisis (Cambridge: Cambridge University Press, 2001); Feredoun Hoveyda, The Shah and the Ayatollah: Iranian Mythology and Islamic Revolution (Westport: Praeger, 2003); Hamilton Jordan, Crisis: The Last Year of the Carter Presidency (London: G.P. Putnam's Sons, 1982); Gary Sick, October Surprise: America's Hostages in Iran and the Election of Ronald Reagan (London: I.B. Tauris, 1992); William H. Sullivan, Mission to Iran (New York: W. W. Norton, 1981); and Kurt Waldheim, In the Eye of the Storm (London: Adler \& Adler, 1985).
} 
In assessing Carter's approach to Iran, it is therefore no surprise that despite an overall expectation that he would reduce arms sales, there was little doubt that Iran would be an exception to the rule and a signal that his grander ambitions for arms limitation would be doomed. Iran represented a vitally important strategic asset for the U.S. in the Persian Gulf region and by continually bolstering its military capabilities, it only further entrenched the area as a U.S. stronghold during a bipolar struggle for power with the Soviet Union. With Saudi Arabia lingering in military backwardness and political instability, and Israel engaged in a bitter series of conflicts with its Arab neighbors - Iran was the most reliable, and able, U.S. security partner in the region. Consequently, Carter's Iran policy came to reflect the more strategically minded policy path inherited from his predecessors. While there is a clear trend in the extant literature concurring that Carter was gradually forced to abandon his ideals due to the constraints of the Cold War, ${ }^{2}$ no account fully investigates the AWACS sale to Iran. ${ }^{3}$ Occurring only a few months into his tenure, the decision to sell the AWACS to Iran was an early, if not the earliest, indicator that Carter's idealism was on a collision course with reality - most notably on arms sales to Iran. The episode also yields a new insight into Carter's personal disposition as his designs for a new turn in U.S. foreign policy became unmoored during his first year in office.

\section{Arming the Shah}

Iran had become America's largest arms customer long before Carter's emergence as a presidential candidate in the mid 1970s. Due to Iran's geographical location it quickly became a focal point in U.S. containment policy in the 1940s, and acted as a bulwark to restrict Soviet access to the oil reserves of the Persian Gulf which accounted for more than $60 \%$ of the world's supply. ${ }^{4}$

2 For the most recent examples see Christian Emery, US Foreign Policy and the Iranian Revolution (New York, Palgrave, 2013) pp 1-92 and Luca Trenta, 'The Champion of Human rights Meets the King of Kings: Jimmy Carter, the Shah, and Iranian Illusions and Rage', Diplomacy and Statecraft, 24: 3 (2013) pp. 476-498.

3 There is an awareness of the AWACS affair in recent literature, however accounts only deal with it in passing, see: Christian Emery, US Foreign Policy and the Iranian Revolution, p. 35; and Luca Trenta, 'The Champion of Human Rights Meets the King of Kings', p.481. Both accounts deal with the issue over less than one paragraph.

${ }^{4}$ See: Kristen Blake, The U.S.-Soviet Confrontation in Iran, 1945-1962: A Case in the Annals of the Cold War (Boulder: University Press of America, 2009); Richard W. Cottam, Iran and the United States, A Cold War Case Study (Pittsburgh: University of Pittsburgh Press, 1988) pp. 66-78; Justus D. Doenecke, 'Revisionists, Oil, and Cold War Diplomacy', Iranian Studies, 3:1, (1970) pp. 96-105; John L. Gaddis, The United States and the Origins of the Cold War 1941-1947 (New York: Columbia University Press, 1972) pp. 309-360; Gary R. Hess, 'The Iranian Crisis of 1945-46 and the Cold War', Political Science Quarterly, 89:1 (March, 1974) pp. 117-146; Joseph M. Jones, The Fifteen Weeks: February 21-June 51947 (New York: The Viking Press, 1955) pp. 
Due to Iran's political, social, and economic instability, a series of U.S. military and economic aid programs were established with Iran for the first two decades of the Cold War. In addition, a U.S.-U.K. coup was staged in 1953 to remove a revisionist left-leaning coalition and ensure that Iran remained governed in a way favourable to the western powers, with the Shah at the centre of affairs. ${ }^{5}$ This support for the Shah's regime was enhanced by a series of arms sales in the mid-1960s as the Shah began to use his growing oil income to look beyond the more restrictive military aid programs he had been gifted in the past. ${ }^{6}$ While a path regarding U.S. arms flowing into Iran was already in place by the end of the 1960s, the significant developments that impacted upon the Carter administration were set into motion by Richard Nixon in May 1972. In a meeting with the Shah in Tehran, Nixon agreed to unlimited and unmoderated arms sales with Iran - with the exception of nuclear weapons technology - in return for the understanding that Iran would use its newfound might to protect the Gulf by proxy. ${ }^{7}$ This gesture, the so called blank check, effected a sharp turn in U.S. arms sales policy. It liberated the Shah from the administrative oversights that had been in place for decades in Washington for foreign arms purchasers. The Shah was free to buy whatever advanced American weaponry he chose, so long as he could pay for it. It was a unique arrangement for a foreign leader and also a test case for Nixon's reimagining of U.S. Cold War strategy based (in part) on outsourcing the costs of containing communism to able allies and clients - the so-called Nixon doctrine. In addition, the moderating effect of Congress was bypassed in a shrewd, and covert, executive manoeuvre of Nixon's imperial style of leadership that left Congress in the dark for several years on the finer details of arming Iran. Yet, Nixon's exclusion of Congress would eventually haunt Carter. A major facet of the AWACS sale in 1977 revolved around Congress viewing it as a tipping point moment to restore their influence over arms sales in a period when executive control had withered from the heights of the early 1970s.

50-58; George Lenczowski, Russia and the West in Iran, 1918-1948: A Study in Big Power Rivalry (New York: Cornell University Press, 1948) pp. 263-315; Robert Rossow Jr, 'The Battle of Azerbaijan, 1946', Middle East Journal, 10: 1 (1956, Winter), pp.17-32.

${ }^{5}$ See Stephen Kinzer, All the Shah's Men: An American Coup and the Roots of Middle East Terror (New Jersey: John Wiley and Sons, 2003); Steve Marsh, 'Continuity and Change: Reinterpreting the Policies of the Truman and Eisenhower Administrations toward Iran, 1950-1954', Journal of Cold War Studies, 7:3 (Summer 2005) pp. 79-123; Steve Marsh, Anglo American Relations and Cold War Oil: Crisis in Iran, (Hampshire, Palgrave Macmillian, 2003); Kermit Roosevelt, Countercoup: The Struggle for the Control of Iran (New York: McGraw Hill, 1979); and Daniel Yergin, The Prize: The Epic Quest for Oil, Money and Power (London: Simon and Schuster, 1991), pp. 420-478.

${ }^{6}$ See Stephen McGlinchey, 'Lyndon B. Johnson and Arms Credit Sales to Iran 1964-1968', Middle East Journal, 67:2 (Spring 2013)

${ }^{7}$ See Roham Alvandi, 'Nixon, Kissinger, and the Shah: The Origins of Iranian Primacy in the Persian Gulf', Diplomatic History, 36: 2 (2012); and Stephen McGlinchey, 'Richard Nixon's Road to Tehran: The Making of the U.S.-Iran Arms Agreement of May 1972', Diplomatic History, 37:4 (2013). 
Nixon designed the blank check policy partly as a response to the British announcement in 1968 that they would make a military withdrawal from their former colonial territories in the Gulf. Upgrading Iran to fill the vacuum left by the British would bypass the political and military complications of direct application of U.S. forces in another region in the wake of Vietnam. By allowing the Shah to fulfil his long held ambitions to build a peerless regional military, the U.S. could still achieve its aims of containment in the Gulf, and it could do so at little to no cost by employing Iran as a regional policeman. It was a major change in arms sales policy, containment policy, and in the broad context of relations between the U.S. and Iran. The extent of the floodgates Nixon had opened catapulted Iranian arms purchases from being measured at approximately $\$ 150$ million dollars per annum in 1969 to being measured in the multi-billions per annum from 1972 onwards. ${ }^{8}$

Gerald Ford's full support for Nixon's Iran-arms regime through his two and a half years in office, following Nixon's resignation over the Watergate affair, left Carter with no alternative short of a wholesale regional policy rethink which there was negligible appetite for in Washington. This became evident when a study of U.S.-Soviet global competition led by the National Security Council (NSC) in the summer of 1977 concluded that Iran was the area where a 'crisis confrontation' with the Soviets was most likely to occur. The study recommended the creation of a U.S. Rapid Deployment Force, permanently stationed in the Gulf to ensure that the Iranian domino would not fall. ${ }^{9}$ Carter agreed, and signed the study into policy via Presidential Directive (PD) 18 in August 1977. The Pentagon effectively ignored the directive and failed to create the force due to a lack of resources and a lack of will.10 The State Department was similarly unmotivated, continuing to bank on the received wisdom of Nixon's regional policy in which arms sales to Iran were effected to prevent the need for such a local deployment of U.S. military force. ${ }^{11}$ So, while it is fair to say that ideas existed that went beyond Nixon's Gulf strategy to arm Iran as a proxy force, the fact that Carter did not see PD-18 through during 1977-1978 indicated the extent to which prior thinking had hardened into place.

In a more general sense, much has been said about the nature of Carter's foreign policy behaviour, and its failure both in terms of achieving objectives the

\footnotetext{
8 State Department Report, Section II:B, 'The U.S.-Iranian Military Relationship, 19411979'. The Digital National Security Archive - (hereafter 'DNSA'): IR03558.

${ }^{9}$ See 'PRM/NSC 10 - Military Strategy and Force Posture Review, Final Report', undated. JCL. < http://www.jimmycarterlibrary.gov/documents/prmemorandums/prm10.pdf $>$ [accessed 14 March 2011].

10 See William E. Odom, 'The Cold War Origins of the U.S. Central Command', Journal of Cold War Studies, 8:2 (Spring 2002), 52-82, pp. 57-59.

11 Ibid.
} 
president himself valued, such as human rights and arms reductions. Carter's foreign policy was very much built on the assumptions of his predecessors, whether it was intentional or not. The sale of the AWACS to Iran is only one example of a foreign policy developed on assumptions of American self-interest and containment, rather than the rhetorical values espoused by Carter during his presidency. The Carter era of foreign policy was supposed to be different, or at least that was what Carter wanted to believe. What became evident during the Carter years was the difficulty he would have in trying to promote an international policy package that mirrored his personal liberal beliefs during the constraints of the Cold War.

The arms trade was a particularly sensitive area during the Carter era and the administration's approach to arms, and its juxtaposition to other normative issues, are a key aspect of Carter's policy failure. As Gaddis stresses:

The difficulty here was that Carter never related his moral and domestic political commitment to human rights to his geopolitical and (given the alternative) humane commitment to arms control.12

As such, Carter's policy towards Iran during the final phase of the Shah's rule has been referred to as his 'most glaring and costly [foreign policy] inconsistency'.13 This is best encapsulated in the New Year's Eve toast Carter delivered in 1977 in Tehran in which he toasted the Shah for turning Iran into an 'island of stability'.14 It was a fateful moment for Carter as one year later the Shah was forced for flee his own country and the once conservative Iran transformed into a revisionist and regionally destabilising - force. What is most interesting about the wider context of the AWACS case is that it demonstrated that arms sales were actually not restrained in any large-scale manner during Carter's tenure. In the case of Iran, due in part to the AWACS, they actually increased to record levels. Even as the Shah entered his twilight in the summer of 1978, another multi-billion dollar arms deal was being tabled with Iran and the Cold War was once again growing hotter creating a need for increased U.S. defense spending. In addition, a major facet of Carter's Camp David accords between Egypt and Israel was a multi billion-dollar package of arms sales to both nations (and also to Saudi Arabia) which Carter advanced to make each party feel more secure and thereby more inclined to sign on to his peace plans. In short, despite rumours to the contrary, Carter was not shy of selling arms.

12 John Lewis Gaddis, Strategies of Containment (Oxford: Oxford University Press, 1982), 348.

13 Walter LaFeber, America, Russia and the Cold War (New York: Alfred A. Knopf, 1985), 288.

14 Jimmy Carter: 'Tehran, Iran Toasts of the President and the Shah at a State Dinner', December 31, 1977. The American Presidency Project. http://www.presidency.ucsb.edu/ws/?pid=7080 [accessed July 14, 2014]. 
It did not take long for Iran arms issues to enter the agenda in 1977. Just five days after Carter had been inaugurated the Iranian Ambassador to the U.S., Ardeshir Zahedi, visited Zbigniew Brzezinski, Carter's National Security Adviser, at the White House. Zahedi reminded Brzezinski that a 'new phase of relations' had been established based around the multi billion-dollar military purchases Iran had made since 1972. He also referred to unspecified agreements made with the Ford administration to raise Iran's military and civilian purchases by anywhere between $\$ 15$ and $\$ 50$ billion over the coming years. Zahedi's vagueness over the exact figures captured neatly just how Iran's business with the U.S. was becoming ever deeper, yet ever more difficult. The bulk of Zahedi's upper $\$ 50$ billion figure was for a nuclear energy deal which the Ford administration had failed to agree terms on with the Shah - something Carter would in fact close a deal on the following year. The accounting also factored in an elusive oil-for-arms barter agreement that the Shah had been pursuing for over a decade. Hence, both of these unconsummated proposals contributed to the speculative upper total. The $\$ 15$ billion at the lower end of Zahedi's estimate was comprised of pending arms sales such as the AWACS, multiple fleets of F-16 fighters and lower order military equipment, spares and ammunition. With this significant level of business pending, Zahedi candidly asked if there were any issues on which disagreement could be expected between Iran and the new administration. Brzezinski replied only in general terms, noting that disagreement should be expected due to the complexity of the relations between the two nations, and noted that a full discussion on arms sales with Iran would be forthcoming. ${ }^{15}$

Pressure was not just coming from the Iranian side, there had been an anti-arms sentiment building through the 1970s on Capitol Hill. ${ }^{16}$ To gauge this for himself, Carter summoned a cross section of Congressional leaders to the White House on 1 February. The Congressional delegation welcomed Carter's general ideas on arms reduction but very quickly narrowed in on discussing specific cases. In a thinly veiled reference to Iran, Senator Frank Church noted that arms sales to Middle Eastern nations had run out of proportion to the domestic needs of those countries. In a more direct tone, Representative Lee Hamilton announced his intention to work towards the 'deny and delay' of arms sales to Israel and Iran. Cyrus Vance, Carter's Secretary of State, noted in response to both Hamilton and Church that 'we will sink the peninsula if we keep

\footnotetext{
${ }^{15}$ For this entire paragraph, see: Memorandum of Conversation: Zahedi, Brzezinski, and William B. Quandt, 25 January 1977. JCL. National Security Affairs Collection 7. Brzezinski Material, Subject File: Meat Import Program: 11/77-8/78 through Memcons: Brzezinski: 3-6/79. Box 33. Folder: Memcons, Brzezinski, 1-9/77.
} 
selling arms.'17 Whilst the Congressional positions were consistent with past behaviour, Vance's concurrence was a strong signal to the Congressional delegation that the Carter administration intended to be true to their arms control promises made on the campaign trail. Carter's choice to remain silent as Vance spoke was likely due to a realisation that arms control rhetoric was easier to voice when he was merely campaigning for President.

On 7 February 1977 Carter made his first official contact with the Shah, exchanging via letter the usual diplomatic pleasantries and expressing his wish to maintain what he referred to as a 'firm relationship' with Iran. Beyond that reassurance, Carter noted that there were serious challenges ahead. Despite the large order of business on the table, arms were not mentioned directly. This was a deliberate attempt by Carter to reshape the contours of diplomacy with Iran. What Carter did mention directly was that:

In the long run, peace and economic progress are indivisible, and there are no nobler tasks for us to work toward together. At times our approaches to these problems may naturally differ, but these will be differences between close and reliable friends, approached in an atmosphere of shared understanding. ${ }^{18}$

The Shah had the letter praised on Iranian state television, leading to confusion within the Carter administration which had been expecting a more subdued reaction. Brzezinski was convinced that the Shah 'disliked the letter' and had merely acted otherwise in order to maintain a domestic façade that it was business as usual in the U.S.-Iran relationship. ${ }^{19}$ As the discussion continued in the following days the general impression converged with Brzezinski's view that the Shah's reaction was likely a domestic public relations stunt and private discontent would doubtless be forthcoming. Encapsulating this line of thinking, Gary Sick, who led Iranian policy at the NSC, noted to Brzezinski:

That is the price we must expect to pay if we intend to pursue an independent policy on such issues as oil prices, and arms transfers which may not always be what the Shah would like to hear from us. ${ }^{20}$

17 See, Memorandum For The Record: 'Foreign Policy and National Security Issues for the 95th Congress', 2 February 1977. JCL, National Security Affairs, Brzezinski

Material, Subject File, Box 50. Folder: Presidential Memos for the Record, 2-6/77.

${ }^{18}$ Letter from Carter to the Shah, 7 February 1977. JCL. Plains File. Box 23, Folder: Iran 6/75-12/79.

${ }^{19}$ See Brzezinski's handwritten notes on NSC 'Evening Report', 10 February 1977. JCL. 'Remote Archives Capture Program' (Digitized archival records located on computer disk at the JCL. Hereafter RAC): NLC-3-9-6-1-2; and note from Rick Inderfurth to William Quandt and Gary Sick, 11 February 1977. JCL. RAC: NLC-15-20-1-2-0.

${ }^{20}$ Memorandum from Sick to Brzezinski, 12 February 1977. JCL. RAC: NLC-15-20-1-2-0. Gary Sick has read a draft of this article and confirmed the accuracy of this analysis. 
Whilst Carter's letter was by no means indicative that his administration would reject all arms sales with Iran, it was a clear signal of a change in the order of business. Considering the general philosophy over arms within the new administration, and the mood on Capitol Hill, the Shah had good reason to be worried. Carter's letter, taken together with the aforementioned statements made by Vance, Brzezinski and Sick, was the deathblow to Nixon's blank check with Iran. However, it did not necessarily mean that arms sales to Iran would end.

\section{Arms Control and the AWACS Sale}

As tentative diplomatic contacts were being made between the Shah and the new administration, Carter set into motion Presidential Review Memorandum (PRM) 12 into general U.S. arms transfer policy, which was chaired by Cyrus Vance. ${ }^{21}$ As the various studies progressed, Vance became an unlikely motor within the administration in favour of a permissive arms sales regime with Iran, despite his earlier statements in support of arms restraint. Vance was the receiving end of regular alarmist telegrams reporting on the Shah's mind-set from the Embassy in Tehran, and as a result he grew impatient. He petitioned Carter to bypass the review process and expedite the bulk of the multi-billion dollar pending arms sales in order to prevent production bottlenecks and serious 'political problems' in bilateral relations with Iran.22 Carter rejected this and noted that he would assess each case individually, and the review process should run its course. ${ }^{23}$ In hindsight, Vance's plea would be the first detectable moment from within the administration that regional strategic concerns would sometimes need to trump the arms idealism of the new administration. Though at this point, Carter remained wedded to his principles.

Vance delivered the results of PRM-12 in early April, after which Brzezinski's NSC team added its own reflections and consulted with both the House International Relations Committee and the Senate Foreign Relations Committee. ${ }^{24}$ Hence, the process was open and inclusive - reflecting Carter's intention to run foreign policy with a team approach. Carter personally reviewed

21 See Memorandum for Brown from 'Captain Coll', 3 March 1977. DNSA: IR01152.

${ }^{22}$ Memorandum from Vance to Carter, 7 March 1977. JCL. Plains file. Box 37. Folder: State Department Evening Reports, 5/77.

23 See Carter's handwritten instructions on: Memorandum from Vance to Carter, 7 March 1977. JCL. Plains file. Box 37. Folder: State Department Evening Reports, 5/77.

24 There are no specific details of what exactly was outlined by Vance, or what the NSC / Congress offered in response and the various conflicts (if any). Those documents remain classified. However, the established trajectory of the review reaching Carter is outlined here: 'President's Reorganization Project', June 1977. JCL. Donated Historical Material, James T. McIntyre Collection. Box 10: Folder 'President's Reorganization Project - Decision Analysis Report, 6/77. 
the various positions and delivered his chosen course of action with Presidential Directive (PD) 13 one month later. PD-13 set the tone for arms sales throughout the Carter administration and put into policy the philosophy that Carter had brought with him into the White House. It established a policy of restraint in the sale of conventional arms to allied nations:

Arms transfers are an exceptional foreign policy implement, to be used only in instances where it can be clearly demonstrated that the transfers contribute to our national security interests. ${ }^{25}$

PD-13 was not just a statement of Carter's intention to deliver on his electioneering promise of arms restraint. The document also outlined that economic impact assessments would be made on less developed recipients of arms. This restored the logic of arms sales that had been evident from the Truman administration through to the Johnson administration. Nixon overturned that logic in 1972 when he determined that the only conditions the Shah would be subjected to was whether he could make his credit payments and that nuclear weaponry was forbidden.

Aside from the broader statements of intent within PD-13, it set out several specific conditions - each of which had direct implications for future U.S.Iran arms sales. Firstly, PD-13 prohibited the introduction of any technology that was not yet fully integrated and operational within the U.S. military apparatus. Secondly, it committed the U.S. to not be the first nation to introduce a qualitatively advanced new weapons system into a region. When considering the nature of Iranian arms build-up thus far, this was sure to cause problems for the Shah. Thirdly, PD-13 contained a directive to only advance sales that did not require the deployment of American contractors. This was highly noteworthy when considering that Iran was deeply dependent on a large, and ever increasing, number of U.S. technicians and engineers. The final point of note in PD-13 was the introduction of a limit on arms sales. The 1977 federal year arms sales figure would serve as a ceiling, with each successive year thereafter reducing on the prior year's total.

The reaction to PD-13 on Capitol Hill was, at best, mixed. It would take time, and a series of tests for Congress to establish its position. But, there was a general concern that the numerous exceptions and conditions would result in a more permissive level of sales than the Congress was happy to see. ${ }^{26}$ Concern of a different nature came from within the staffer levels of the Departments of State and Defense. Therein concern arose that security relationships with key allies would be impacted negatively by what appeared to be an arbitrarily

25 Presidential Directive 13, 13 May 1977. Available at < http://www.fas.org/irp/offdocs/pd/index.html> [accessed 13 August 2015]. 26 See Lucy W. Benson, 'Turning the Arms Supertanker: Arms Transfer Restraint', International Security, 3: 4 (1979), 3-17. p. 3. 
restrictionist policy, reflecting on Vance's warning. ${ }^{27}$ To those experienced staffers, PD-13 seemed to indicate that that valued foreign allies such as Iran would be humiliated into pleading on a case-by-case basis for their basic security needs. This is exactly what occurred with the Shah some months later when he made his official request to buy the AWACS.

The Airborne Warning and Control System (AWACS) was a highly modified and militarised Boeing 707 jet fitted with a large revolving radar dome that served as a high altitude airborne command centre. Although the system was outwardly defensive and carried no weapons, it provided a force multiplier effect that enhanced the user's offensive capabilities. The ambiguity with the AWACS was due to the fact that it explicitly allowed for the monitoring and location of enemy stationing and battlefield movements; both ground and airborne. Yet, implicitly (and simultaneously) it enabled the offensive coordination of the user's forces. For example, Iran could use the system to direct one of its fighter jets to an attack target beyond Iranian borders. Put simply, the AWACS was a high-tech eye in the sky, able to cover thousands of square miles per flight. Although there were pre-existing primitive cousins of this system in both Soviet and US hands, the AWACS (officially titled the E-3 Sentry) was the most advanced early warning system available at the time and was a generation ahead of competitor systems. And, the system is still in service today.

Iran had expressed interest in purchasing a fleet of AWACS as early as 1974 when the prototypes were being developed as part of a $\$ 1.5$ billion U.S. Air Force program. Under Nixon's arms regime, the Shah had been able to access prototype systems, and regularly attended military demonstrations. There was a consensus during the Ford years that due to Iran's proximity to the Soviet Union and its large landmass, the Shah had a good case to make for the purchase of an airborne radar system rather than the more conventional ground based systems. Under Ford, the Shah's initial estimates of needing seven AWACS to patrol his airspace had been increased to between nine and ten due to joint US and Iranian assessments. ${ }^{28}$ Yet, production delays in the AWACS development cycle prevented any final deal from being sealed with Iran during the Ford years.

Although U.S. arms sales were on hold in the first half of 1977 awaiting the arrival of PD-13, Carter decided to go ahead with the sale of five AWACS to

\footnotetext{
27 Memorandum from Brzezinski to Carter, 11 November 1977. JCL. Zbigniew Brzezinski Collection, Box 41, Folder: Weekly Reports to the President, 31-41: 10/77-1/78.

${ }^{28}$ See, 'Iranian Air Defense Improvement Study', U.S. Air Force Telegram to the MAAG in Tehran, 13 January 1977. DNSA: IR01126; and, Letter from the Shah to Carter, 27 April 1977. Jimmy Carter President Library (hereafter JCL), Plains file, Box 23, Folder: Iran, 6/75-12/79.
} 
Iran in mid April. Carter's decision was reached despite internal opposition from CIA Director, Stansfield Turner. Turner opposed the sale due to fears of the Soviet Union gaining access to the sensitive technology on-board the craft either through espionage or capture. ${ }^{29}$ The tide flowing in the opposite direction came chiefly from the Air Force who hoped that the additional AWACS sales would lower production costs and enable some of the significant research and development costs to be recouped. ${ }^{30}$ Additionally, there was diplomatic pressure on Carter as both Nixon and Ford had given informal assurances to the Shah that he would be sold the AWACS. ${ }^{31}$

The decision to sell Iran only five AWACS was notable on several levels. Firstly, it was half of the Shah's request. This immediately presented effectiveness issues with the fleet possibly not being able to cover Iran's airspace, thereby making the system unfit for purpose. This gesture was typical of Carter's approach to problems - to attempt to engineer a compromise that would suit both sides. It was also an attempt to avoid appearances that he was being hypocritical in brokering such a significant arms deal despite his campaign rhetoric. Selling less of the craft would allow Carter to show to the Congress and to the public that he was serious about arms control, while also remaining faithful to America's allies. Secondly, a point unknown to the Shah, ${ }^{32}$ was that the sale was to go ahead only after extensive sanitising of some of the highly sensitive equipment on each craft, rendering the Shah's AWACS materially different from the U.S. Air Force models. This was, again, envisioned as a compromise to deflect fears of the sensitive technology falling onto Soviet hands. To Carter this all seemed like an acceptable compromise. Compromise, then, is the important issue to hold on to at this point. Very early in his tenure it is clear that Carter is less absolute than he appeared some months earlier on the campaign trail. And, those wishing to detect a crack in Carter's arms control aspirations might consider this to be the first one of significance.

Upon being notified of the AWACS offer in mid April, the Shah saw the development as the beginning of a barter process and immediately pleaded for nine craft. In a letter to Carter on 27 April the Shah seized upon the unfit for

${ }^{29}$ Lawrence J. Korb, 'National Security Organization and Process in the Carter Administration', in Sam Sarkesian (ed.) Defense Policy and the Carter Presidency: Carter's First Years (Boulder: Westview Press, 1979), p.133; Also see Memorandum from 'Global Issues' for Brzezinski, 12 July 1977. JCL. RAC: NLC-28-36-2-18-1.

${ }^{30}$ Paul Y. Hammond, David J. Louscher, Michael D. Salomone and Norman A. Graham, The Reluctant Supplier: U.S. Decisionmaking for Arms Sales (Cambridge, Massachusetts: Gunn and Hain, 1983), p.35.

31 See: Joanna Spear, Carter and Arms Sales: Implementing the Carter Administration's Arms Transfer Restrain Policy (London: Macmillian, 1995), pp. 132-133.

32 Memorandum from 'Global Issues' to Brzezinski, 10 June 1977. JCL. RAC: NLC-10-3-217-7. 
purpose argument - i.e. that five craft would not be sufficient coverage for Iranian defense purposes. This was a strong bargaining position considering the prior U.S.-Iranian study on how many AWACS Iran would need. ${ }^{33}$ Carter was manoeuvred into a corner, but he was not yet ready to countenance a concession with the Shah. Vance was expecting to deliver some kind of resolution to the AWACS impasse during a visit to Tehran in mid May. Yet, as his briefing notes were being prepared no consensus was forming over whether a concession of some kind was necessary. In preparation for the trip, Vance was advised by Alfred L. Atherton, Jr. at the State Department's Near Eastern Affairs Division to expect the Shah to once again request nine AWACS - and if so to deflect the issue. $^{34}$ Such was the level of indecisiveness within the administration that Vance was forced to seek final clarification on the eve of his visit on the status of the deal. This clarification did not come forcing him to leave with no compromise authorised beyond the initial offer for five AWACS. 35

Despite the uncertainty over the AWACS offer, Vance was able to secure a commitment that the Shah's request for 160 F-16 fighter jets, advanced in September 1976, would be approved. The addition of these F-16s, when added to the $80 \mathrm{~F}-14 \mathrm{~s}$ that the Shah had purchased earlier in the decade, gave Iran (on paper) one of the most sophisticated air forces in the world. Hence, Vance's visit would at the very least be delivering some good news to the military-minded Shah. Vance was also briefed to demur on the Shah's intentions to purchase a further 140 F-16s. ${ }^{36}$ Again, Carter's overriding persuasion was one of compromise and an attempt to portray balance. As the first F-16 deal predated the Carter administration, and was rubber-stamped by Ford, ${ }^{37}$ there was less of a political minefield in allowing it to progress. However, by halting a second tranche of F-16s Carter could appear to be drawing a line under the permissive arms sale regime that had characterised the Nixon/Ford years.

Whilst the Carter administration had begun to institutionalise a framework of moderation and reflection on arms sales during 1977, the Shah stood firmly outside this orbit and continued to doggedly pursue his objectives. When Vance reported back to Carter following his visit to Tehran, Carter decided to offer the Shah seven AWACS as a further compromise - essentially meeting the

33 See Letter from the Shah to Carter, 27 April 1977. JCL. Plains file, Box 23, Folder: Iran, 6/75-12/79.

34 Briefing Memorandum from Alfred L. Atherton, Jr. (NEA) to Vance, 30 April 1977. DNSA: IR01164.

35 Memorandum for Brzezinski (no sender detailed), 12 May 1977. JCL. RAC: NLC-1-2-317-7.

${ }^{36}$ Briefing Memorandum from Alfred L. Atherton, Jr. to Vance, 30 April 1977. DNSA: IR01164.

37 Memorandum From Clinton E. Granger to Scowcroft, 13 September 1976. GFL. Presidential Country Files, Iran, Box 13. 
Shah halfway. ${ }^{38}$ There seemed no indication that the Shah wished to push further upon being notified of this compromise, and he appeared content with seven AWACS. ${ }^{39}$ Additionally, Carter invited the Shah to Washington in November to put their relationship on a personal level. As with countless occasions in the past, this was an opportunity the Shah gratefully accepted. Underscoring the longevity of the Shah's reign, Carter would be the eighth U.S. President he would meet whilst on the Peacock throne.

\section{AWACS and Congress}

Due to Nixon's imperial-styled control over arms sales, with Iran forming a stand-out case, Congress had appropriated the authority via the 1974 NelsonBingham amendment to independency scrutinize all major arms sales. Such bureaucratic issues were irritating for the Shah, who had become accustomed to the unmoderated access of the Nixon arms regime. The Nelson-Bingham amendment ${ }^{40}$ stipulated that arms sales over $\$ 25$ million and equipment sales over $\$ 7$ million were to be submitted to Congress - upon which event it would have thirty days to approve or reject the sale. If both Houses of Congress concurrently opposed a sale by majority vote, it would become void. Though, if one House approved a sale, it would proceed.

In March 1976 Congress had exercised its new statutory powers to hold up a comparatively minor sale of C-130 transport aircraft to Egypt. This raised alarm that Iran may be next in the Congressional firing line. ${ }^{41}$ By the summer of 1976 it had become apparent to Henry Kissinger, Ford's Secretary of State and key advocate for the Iran-arms sale regime, that there was a clear 'anti-armssales binge on the Hill'.42 This sentiment was driven not just by a concern within the Congress over arms sales that had been building through the 1970s, but a tide of media scrutiny over the Shah's intentions. Inaccurate reporting in the U.S. press sparked public alarm over a new $\$ 10$ billion arms agreement with Iran, as part of a larger $\$ 50$ billion commercial deal. ${ }^{43}$ The $\$ 10$ billion figure was actually largely comprised of credit repayments, due over the coming five years. Hence, it was for deals already done, such as Iran's purchase of 80 F-14 jets during the

38 'Message for the Shah from President Carter', 24 May 1977. JCL. Plains file, Box 23, Folder: Iran, 6/75-12/79.

${ }^{39}$ Letter from the Shah to Carter, 1 June 1977. JCL. Plains file, Box 23, Folder: Iran, 6/75$12 / 79$.

40 The amendment was later amalgamated into the 1976 Arms Export Control Act.

41 Telegram from Helms to the State Department, 29 March 1976. GFL. Country File, Iran-State Department Telegrams. Box 14.

42 Henry Kissinger: Memorandum of Conversation between Ford, Kissinger and Scowcroft, 13 August 1976. GFL. NSA, Memoranda of Conversations, Box 20.

43 'U.S. Support of Shah of Iran Reinforced By New Pledges During Kissinger's Visit', The Wall Street Journal, 9 August 1976. 
Nixon years. The remaining $\$ 40$ billion was largely accountable to the as-yet unsigned and contentious nuclear energy deal and various other formative arms deals and infrastructure projects. ${ }^{44}$ The episode chimed with a growing unease towards the Shah and his relations with the U.S., principally via his rapidly growing military and economic power. As the ringleader of the OPEC oil shocks of 1973-74 that quadrupled the price of oil, the Shah had become a divisive figure popularly and politically. ${ }^{45}$ When added to an emergent tide of well publicised activism amongst thousands of Iranian students on U.S. college campuses over the Shah's human rights record, Congressional attitudes over Iran were very much in flux and embodied a general moment of reflection in the U.S. over its relations with the Shah. The nature of the situation in the U.S. sent the Shah into a fit of paranoia that certain interests, including Israel, was lobbying against Iran in Washington and leaking false information in order to damage his reputation. 46

The background to these debates reflected a time of high tension over arms sales between the Congress and the Ford administration that became a new norm replacing the trend of executive dominance seen in the Nixon years. Congressional frustrations were stirred by two underlying problems. This was exemplified by what Senator Hubert H. Humphrey described as a culture of treating arms sales 'as if we were selling televisions and refrigerators and washing machines.' ${ }^{47}$ Firstly, Congress clearly desired a fuller consultation role in examining arms deals before they were agreed and simply rubberstamped under the Nelson-Bingham system. Senator Clifford P. Case addressed this problem acutely, using Iran as an example:

We are not really going to be able to review something if the Shah of Iran has already been told he is going to get it 3 or 4 years ago and if he has made all his own plans and staked his prestige in part on the promise that he is going to get it. Our relations with Iran are going to suffer if we exercise effectively what the public expects us to exercise; namely, a normal oversight function. ${ }^{48}$

\footnotetext{
44 Telegram from Helms to the State Department, 26 August 1976. GFL. Country File, Iran-State Department Telegrams. Box 14.

45 See Roham Alvandi, Nixon, Kissinger and the Shah (Oxford, Oxford University Press, 2014) pp. 147-152.

${ }^{46}$ Asadollah Alam, The Shah and I, pp. 504, 515-516; Also see, Telegram from Helms to the State Department, 25 September 1976. GFL. Country File, Iran-State Department Telegrams. Box 14.

47 Statement by Senator Humphrey, 16 September 1976. 'U.S. Arms Sales Policy: Hearings before the Committee on Foreign Relations and the Subcommittee on Foreign Assistance, September 16, 21, and 24, 1976'. U.S. Government Printing Office, Washington D.C.

48 Testimony of Senator Case, 16 September 1976. 'U.S. Arms Sales Policy: Hearings before the Committee on Foreign Relations and the Subcommittee on Foreign
} 
Secondly, a thinly veiled Nixon/Ford administration strategy to neuter the effectiveness of the Congressional oversight on arms had led to abuse of the process in the form of not only serially withholding requests for classified executive documents on various arms agreements (such as Nixon's blank check), but also via the dumping of multiple arms sales all at once giving the Congress little time to scrutinise them properly. Hence, as the Carter administration entered office there was a clear trend of increasing oversight, and increasing frustration, on Capitol Hill over arms sales to Iran.

Inevitably, the Senate took a close interest in the sale of the AWACS to Iran and conducted a series of hearings in July 1977. Considering that Congressional scrutiny of the AWACS programme itself had been longstanding due to spiralling costs and development problems, the Senate was well versed on the challenges it would pose to an Iranian team of operators. Senators Thomas F. Eagleton and John C. Culver voiced the primary concerns during an 18 July hearing of the Subcommittee on Foreign Assistance. Senator Eagleton stressed that the sale would result in an unacceptable increase in American technicians in Iran, deployed to assist and train Iranian AWACS operators. Further, it raised the inevitability that should Iran's forces be called into combat, those technicians would be on-board Iran's AWACS fleet, putting American lives in jeopardy assisting in a foreign war. ${ }^{49}$ Senator Culver, who had extensive knowledge of the AWACS and had flown on prototype demonstrations, elaborated further noting that it took over one year to train 'the most menial' position within a seventeen member AWACS crew. Yet, Iran was so backward in basic modern skillsets within its domestic population that it had to regularly look to Korea and the Philippines to find truck drivers to keep its industry moving. ${ }^{50}$ Culver's testimony solidified the gradual feeling evolving within the Senate that the AWACS deal was the point at which the entrenched mind-set toward arming Iran would have to end. In Culver's own words: 'We are trying to reverse a very dangerous policy of 5 years ago, which has got a momentum and a life all of its own, but we have got to draw the line.'51 As previously noted, Carter's broad arms persuasion concurred with the tide in Congress to arrest Nixon's arms regime with Iran. Yet,

Assistance, September 16, 21, and 24, 1976'. U.S. Government Printing Office, Washington D.C.

${ }^{49}$ Statement by Senator Eagleton, 18 July 1977. 'Hearings before the Subcommittee on Foreign Assistance and the Committee on Foreign Relations on Proposed Sale of Seven E-3 Airborne Warning and Control System Aircraft to Iran: July 18, 22, 25, 27 and September 19, 1977', U.S. Government Printing Office, Washington D.C. 1977.

50 Statement by Senator Culver, 18 July 1977. 'Hearings before the Subcommittee on Foreign Assistance and the Committee on Foreign Relations on Proposed Sale of Seven E-3 Airborne Warning and Control System Aircraft to Iran: July 18, 22, 25, 27 and September 19, 1977', U.S. Government Printing Office, Washington D.C. 1977.

${ }^{51}$ Culver, 18 July 1977. 
this would only be a shallow point of agreement, which the AWACS sale would sorely test.

The mood in the White House following the Senate hearings was sombre. Brzezinski was briefed by his staffers at that this was 'the strongest challenge of an intended arms sale to date', and if a vote had been taken there and then, the result would have been foreboding for the administration. ${ }^{52}$ In the days following the hearing, Carter began to receive pleas from otherwise sympathetic Senators to withdraw the sale. The accusation was that it was delivered prematurely (due to pressure from the Shah) and at a time in which the Senate was backlogged with other legislative issues. Robert C. Byrd, Senate Majority Leader, wrote to Carter restating the concerns of Senators Culver and Eagleton and conveyed the 'considerable controversy' that the issue had generated on Capitol Hill. He added that NATO partners had not even yet had notice of when they would be receiving the AWACS - making the decision to prioritise an Iranian sale indefensible to Congress. ${ }^{33}$ Carter discussed the issue with Brzezinski before deciding not to withdraw the sale. ${ }^{54}$

The Subcommittee on Foreign Assistance held its second AWACS meeting on 22 July. This time the hearings featured testimony from the Departments of State and Defense. Both Vance and Carter's Secretary of Defense, Harold Brown, left the task to lower order staff: The Department of State was represented by Assistant Secretary of State for Near Eastern Affairs, Alfred L. Atherton Jr.; while Erich Von Marbod, the acting Director of the Defense Security Agency, represented the Department of Defense. Both Marbod and Atherton repeated the administration line and sought to offer assurances. ${ }^{55}$ However, their efforts were overshadowed by events outside their control. During late May, Stansfield Turner had been approached by a delegation of Senators (Culver, Eagleton, Proxmire, Mathias, and Nelson), ${ }^{56}$ who drafted a letter requesting classified information on the AWACS sale. Turner took the liberty of despatching a frank response on 8 July, answering each of the Senators questions in detail, and listing

52 Memorandum from 'Global Issues' to Brzezinski, 18 July 1977. JCL. RAC: NLC-28-36-220-8.

53 Letter from Robert C. Byrd to Carter, 22 July 1977. JCL. Handwriting File. Box 39, Folder: 7/23/77.

${ }^{54}$ See Carter and Brzezinski's notations; Letter from Robert C. Byrd to Carter, 22 July 1977. JCL. Handwriting File. Box 39, Folder: 7/23/77.

55 See testimony of Atherton/Marbod and Q\&A: Sale of AWACS to Iran, 22 July 1977. 'Hearings before the Subcommittee on Foreign Assistance and the Committee on Foreign Relations on Proposed Sale of Seven E-3 Airborne Warning and Control System Aircraft to Iran: July 18, 22, 25, 27 and September 19, 1977', U.S. Government Printing Office, Washington D.C. 1977.

56 The Senators were members of the Senate Subcommittee on Foreign Assistance and had each taken an active interest in the AWACS sale to Iran. 
his exact security concerns about selling the AWACS to Iran. ${ }^{57}$ After receiving the letter, Humphrey's Subcommittee called Turner to a secret session on the morning of 22 July, before the public hearings, where he testified that no matter how much the technology in the AWACS was sanitised, it would still be an unacceptable risk to place the AWACS in Iran. ${ }^{58}$ This opened up an entirely new headache for Carter. Turner had given the Congress powerful ammunition in their case to reject the sale, and he had exposed a deep division within the administration.

Despite the ever-lengthening odds, Carter was not ready to give in. Vance and Brown were despatched to reassure Congress that no AWACS would be sent to Iran without fully developed security measures in place. ${ }^{59}$ This would be the high-level push that the previous testimony by Atherton and von Marbod had lacked. The 'big pitch' over the AWACS sale, personified by the Vance-Brown offensive was, in the end, heavily slanted on the issue of technological sensitivity as raised by Turner. It was therefore doomed to failure. Although Turner's testimony had caused high-level alarm in the Senate, it was merely the straw that broke the camel's back. This short sighted response treated Congressional opposition as a technical issue that could be solved by compromise, rather than fully anticipating the deep alarm that the aggregation of years of multi-billion dollar arms deals with Iran had generated within Congress. These points were clearly visible in the 18 July testimony and in the letter to Carter by Senator Byrd. The inevitable failure materialised, to the extent that word reached Brzezinski days later that Vance and Brown's efforts actually had the result of strengthening opposition to the sale. ${ }^{60}$

Carter received a letter on 27 July from Humphrey confirming that the Subcommittee on Foreign Assistance had submitted a proposal to the Senate Foreign Relations Committee to block the AWACS sale if it was not immediately withdrawn for further study. ${ }^{61}$ The same day the House Committee on Foreign Relations secured a majority decision for a concurrent resolution of disapproval for the sale. Even the three Democrat Party Senators within the Foreign

${ }^{57}$ See Memorandum from Brzezinski to Carter: 'AWACS to Iran' (undated). JCL. RAC: NLC-15-20-1-12-9; and, Memorandum from Vance to Brzezinski, 14 July 1977. JCL. RAC: NLC-16-40-3-23-2.

58 Turner's testimony reflected his letter, and while that letter and testimony remain classified, his thesis can be clearly determined from the discourse of the various Senators and administration officials. For one example amongst many see Memorandum from Vance to Brzezinski, 14 July 1977. JCL. RAC: NLC-16-40-3-23-2.

${ }^{59}$ Memorandum from 'Middle East' to Brzezinski, 25 July 1977. JCL. RAC: NLC-10-4-217-6.

${ }^{60}$ See Memorandum from 'Europe’ to Brzezinski, 25 July 1977. JCL. RAC: NLC-10-4-2-167.

61 Letter to Carter from Humphrey, 27 July 1977. JCL. Office of the Congressional Liaison. Box 260. Folder: AWACS. 
Assistance Subcommittee (Senators Church, Clark and Biden) remained opposed to the sale following Turner's revelatory testimony on 22 July, and were unreceptive to Carter's advances. ${ }^{62}$ With no other option, and with his own party members against him, Carter withdrew the AWACS sale on 28 July to prevent it being voted down.

With the efforts by Vance and Brown a failure, both Houses of Congress giving concurrent notice that the sale would be stalled, and with his own Director of Central Intelligence in open revolt against him, Carter still refused to admit defeat. He maintained an unbroken focus on securing the support necessary to make a swift re-submission successful. He took to personally writing to Humphrey as he withdrew the sale, addressing all the major points of concern. Carter reminded Humphrey of the 'pledge' the U.S. had made to Iran concerning its defences, and the AWACS in particular, before restating that the AWACS was a primarily defensive system. Carter assured that further sanitization of the technology would be made prior to sale to allay the fears of Turner, and assured that all training of Iranian crews would take place in America to avoid any risk of U.S. personnel being engaged in Iranian combat missions. ${ }^{63}$ Concurrently, Carter rallied sympathetic Congressmen in a letter writing campaign. ${ }^{64}$

Upon hearing the news of the temporary withdrawal of the sale, the Shah entered the fray. On 31 July Vance had cabled the U.S. Embassy in Tehran stressing that the Shah should be reassured that the withdrawal of the AWACS sale was 'purely and simply' the result of the Senate not having time to deliberate over the sale and there was no hostility toward the sale within the Congress. ${ }^{65}$ The Shah, who had his own insights into business in Washington, saw through Vance's erroneous reassurance. The new U.S. Ambassador to Iran, William Sullivan, reported on 1 August that the Shah had angrily ordered the AWACS sale to be withdrawn entirely. He then opened up enquiries with Britain for comparatively lower order Nimrod radar aircraft and summoned representatives of the British Ministry of Defence to Tehran. ${ }^{66}$ Sullivan attempted to convince the Shah that although the Congressional opposition was a setback, the sale retained full presidential advocacy. Yet, the Shah appeared at 'a turning

\footnotetext{
62 See Briefing Memorandum from Lucy Benson to Douglas J. Bennet, Jr., 19 August 1977. JCL. Office of the Congressional Liaison. Box 260. Folder: AWACS.

${ }^{63}$ See 'Talking Points (AWACS)'; and, Letter from Carter to Turner, 28 July 1977. JCL. Office of the Congressional Liaison. Box 260. Folder: AWACS.

${ }^{64}$ For example, see Letter from Carter to Speaker Tip O'Neill, 28 July 1977. JCL. Office of the Congressional Liaison. Box 260. Folder: AWACS.

65 Telegram From Vance to Embassy Tehran, 31 July 1977. DNSA: IR01208.

66 NSC Briefing Memorandum, 1 August 1977. JCL. RAC: NLC-1-3-3-5-9.
} 
point' and questioned the entire Iran-U.S. relationship. ${ }^{67}$ The very same day reports began to circulate that the Soviet Premier, Brezhnev, had been invited to Tehran. ${ }^{68}$ Together with the Nimrod issue, and taking stock of the Shah's habitual behaviour demonstrated through prior instances when he received resistance over arms sales in Washington, this was certainly a move of high stakes brinkmanship. Jack C. Miklos, who had left the State Department's Iran Desk in 1974 to become Deputy Chief of Mission in the U.S. Embassy in Tehran had briefed Carter of this eventuality at several points through the first half of 1977. At one point he cautioned that, 'decision to cut back supply in Iran would be interpreted as a lowering of US interest in and friendship for Iran, with the attendant consequences.' ${ }^{69}$ Those consequences were not just that Iran would seek high level arms from European nations like Britain and France thereby losing business for U.S. contractors, but that the U.S. would lose vital political influence over Iran as the Shah would look to the Soviets for high level military equipment - something that he had resisted thus far keeping his military purchases with Moscow to more rudimentary items. Recalling Carter's determined efforts through July on the AWACS issue, it was likely this particular round of brinkmanship was aimed at Congress.

As the administration took stock of the AWACS setback, a reinvigorated strategy took shape to push the sale through. Through the second half of August the administration began a high level push to brainstorm additional measures to convince Congress of the need for the sale. Yet, the sticking point remained the testimony of Turner. With Congress looking to draw a line under arms sales and seizing upon the AWACS sale as a case in point, Turner had given Congress more firepower than it was accustomed to having. When compared to the carefully controlled and hierarchical foreign policy apparatus of the Nixon/Ford years, Congress had a new weapon - a divided administration. The mood within the NSC was that if the resubmitted AWACS sale was turned down for a second time in September, the Shah would cancel his November visit and throw the entire U.S. policy towards the Persian Gulf into crisis. ${ }^{70}$ The latter half of 1977 also witnessed growing reports of domestic disturbances, attacks against foreigners, and widespread opposition to the Shah's rule. With these in mind there was an additional fear that the public breakdown in the AWACS sale was adding fuel to instability within Iran by making the Shah look weak. ${ }^{71}$

${ }^{67}$ Memorandum from 'The Situation Room' to Brzezinski, 1 August 1977. JCL. RAC: NLC1-3-3-4-0.

${ }^{68}$ Memorandum from Brzezinski to Carter, 1 August 1977. JCL. RAC: NLC-1-3-3-1-3.

69 'Annual Policy and Resource Assessment for Iran - Part One', 5 April 1977. Sent via telegram from the US Embassy in Tehran to the State Department. DNSA IR01159.

${ }^{70}$ See Memorandum from 'Intelligence Coordination' to Brzezinski, 30 August 1977. JCL. RAC: NLC-10-4-7-12-6.

71 Memorandum from 'Intelligence Coordination' to Brzezinski, 30 August 1977. JCL. RAC: NLC-10-4-7-12-6. 
Turner's position, and his testimony to Congress had also ensured that more modifications of the AWACS technology became a de facto norm within any revised sale. Yet, amazingly, the Shah was never consulted over the exact nature of the downgrades. Nor was he aware that this issue had become a deal breaker. Hence, as Carter prepared to resubmit the sale to Congress, staffers within the NSC, notably Bill Cable and Frank Moore at the Congressional Liaison Office, began to ask whether the Shah would even accept such a sanitized version of the AWACS. This was a problem since much of the technology he was originally attracted to (and was paying for), would end up being removed..$^{72}$ This on-going muddle was nothing new, and had already been predicted by an NSC staffer in a memorandum to Brzezinski two months earlier:

I have a horrible fantasy of going through a terrible fight on the Hill, winning it at the expense of the President's personal intervention (or something comparable), extending the letter of offer with the technical details to Iran, and then being told by the Shah that this isn't at all what he had in mind. The administration's credibility in that case would be severely damaged, to say the least.73

With all this uncertainty in mind, Carter ordered Brzezinski to call 'every member' of the House International Relations Committee to make the renewed case for the sale. This worked on the feeling that there was generally more sympathy in the House than was evident in the Senate..$^{74}$ There also remained an additional issue: timing. If the sale was not passed by the end of September, it would fall within the following federal year (1978). With Carter politically committed to lowering total arms sales under a progressively falling ceiling each federal year, getting the AWACS sale into the 1977 framework took on an added political importance. If the sale was closed before 30 September, it would inflate the 1977 arms total by approximately ten per cent. This would have the positive knock-on effect of raising the 1978 ceiling (as each ceiling was related to the preceding years arms sales), and thereby introduce more flexibility for the following year. If the sale fell after the cut off date, the reverse would be true. Hence, this was much more than a banal accountancy issue. With all eyes on resubmission by the first week of September, Carter would potentially need a favour from Congress to make their decision before the full thirty days period expired on 6 October. With all matters considered, this was a testing moment for Carter.

\footnotetext{
72 Memorandum from Bill Cable to Carter, 26 August 1977. JCL. Handwriting File, Box 46, Folder: 8/27/77.

${ }^{73}$ Memorandum from 'Global Issues' to Brzezinski, 10 June 1977. JCL. RAC: NLC-10-3-217-7.

74 See Carter's handwritten instructions to Brzezinski on; Memorandum from Bill Cable to Carter, 26 August 1977. JCL. Handwriting File, Box 46, Folder: 8/27/77.
} 
The sale was resubmitted to Congress on 7 September. Despite Carter's wish for an accelerated timetable, the Senate Subcommittee on Foreign Assistance was in no hurry and did not reconvene for hearings until twelve days later. The administration had prepared a robust six-point compromise delivered by Harold Brown that answered to the best extent possible the concerns raised in July. ${ }^{75}$ The new sale package also contained a personal assurance from the Shah that Iran's AWACS would only be used defensively. This was an example of the administration throwing every card in the deck at Congress. Adding a promise that the AWACS would only be used defensively is both spurious and operationally impossible. Whilst the Shah's reassurances were unlikely to sway Congress, Turner had fallen into line under the weight of the full-scale administration push for the AWACS sale. He did not retract the substance of his concerns, nor did he proactively back the sale. He simply removed his strong objections and replaced those with a guarded statement that advised Congress that Iran's security record was strong enough to award it the benefit of his doubt. In sum, when added to the further modifications being made to the sensitive technology on board, this should render the AWACS relatively safe in Iranian hands. ${ }^{76}$

The coming together of these factors, when added to the significant lobbying effort conducted throughout August, secured a tight vote for the sale in the more sympathetic House Committee on Foreign Relations. ${ }^{77}$ Hence, with one House of Congress in affirmative for the sale, the ever-critical Senate Subcommittee on Foreign Assistance had no recourse but to drop its objections. The affair would be an all too public glimpse of the repercussions of what NSC staffer Gary Sick called 'clumsy' policymaking within the administration.78 Although the sale had been secured in the end, it had failed to be achieved within the 1977 Federal Year. As explained, this would lead to potential problems in forthcoming arms sales concerning Carter's desire to establish an annual ceiling from 1978 onwards. Additionally, the long drawn out saga had been damaging to the Shah and to the U.S.-Iran relationship, confirming Miklos' fears of any wavering in arms supply policy. In Vance's words:

The effect of this summer-long fight was, perversely, to shake the Shah's confidence in the United States as a dependable ally. He missed the more

\footnotetext{
75 See Memorandum from 'Press/Congressional' to Brzezinski, 6 September 1977. JCL. RAC: NLC-13-9-7-3-8.

${ }^{76}$ See Letter from Turner to Brzezinski, 1 September 1977. JCL. RAC: NLC-7-1-1-12-9.

${ }^{77}$ See Gary Sick, All Fall Down: America's Tragic Encounter With Iran (New York: Penguin, 1986), pp. 30-32; and Cyrus Vance, Hard Choices: Critical Years in America's Foreign Policy (New York: Simon and Schuster, 1983), p. 321.

78 Gary Sick, All Fall Down, p. 32.
} 
open access to U.S. Military equipment he had enjoyed in the early 1970s, and he resented the public criticism. ${ }^{79}$

\section{Carter's Pragmatism}

As the AWACS standoff between Congress and the administration ended, it is worth reflecting upon a wider issue. Carter was not only battling with Congress and members of his own administration such as Turner. In pursuing the sale of the AWACS to Iran, Carter was riding roughshod over two key pillars of his arms policy rethink which had been outlined in PD-13. Firstly, one of the central controls introduced in PD-13 was the decision not to introduce paradigm changing military technology into a region, thereby setting the precedent for arms escalation with the Soviet Union. The AWACS clearly violated this principle, no matter how sanitised Iran's AWACS would be in the end. Secondly, the heart of PD-13 was the establishment of the aforementioned progressively lowering annual arms ceiling. To retain flexibility as this ceiling came into effect, NATO nations, plus Japan, Australia, and New Zealand were exempted due to existing US treaty obligations. PD-13 also excluded Israel, albeit abstrusely, but Iran was conspicuous via its absence from the policy paper as America's largest arms customer. Despite this, Vance later recounted in his memoirs that he had privately reassured the Iranian Ambassador that Iran would also be exempted from PD-13. This led to arguments and frustration within the administration. NSC Staffer Leslie Denend summed it up in a memorandum to Brzezinski as follows:

Though this may seem like a good way to ease the Shah's disapproval of our policy, it seems to me shortsighted in the extreme. Either we mean what Vance has said, in which case we are never going to decrease arms transfers...or else we don't mean it. ${ }^{80}$

What these two points highlight is the extent of the pragmatism embedded at the upper end of the Carter administration - and how early in the administration that pragmatism had set in. Whilst the staffer levels were getting their collective heads around the new arms regime and working hard to establish the policy momentum for PD-13, Vance (and as it would later turn out Carter and Brzezinski), were already introducing fluidity into the process. This begged the question of why Carter bothered to add the specific countries listed in PD-13 as exceptions when he intended to exempt more nations on an ad-hoc basis, such as Iran.

${ }^{79}$ Cyrus Vance, Hard Choices, p. 321.

${ }^{80}$ Memorandum for Brzezinski from 'Global Issues', 31 May 1977. JCL. RAC: NLC-28-362-25-3. 
Focusing on Carter specifically, he cited a diary entry in his memoirs from 31 July 1977 where he noted apathetically (as the AWACS sale had been temporarily withdrawn from Congress) that he did not care whether or not the Shah bought the AWACS. He added that the Shah was welcome to pursue those European alternative systems that he was considering. ${ }^{81}$ If such a sale occurred, those alternatives - such as the Nimrod - would not contravene PD-13's controls, as they were not paradigm changing systems and were relatively backward compared to the AWACS. Carter's curious reflection, when examining the reality of the intense administration scramble to push the AWACS sale through the summer of 1977 - with Carter himself actively directing proceedings - seems bizarrely contradictory. What can be said for sure is that Carter's professions to Congress, to the Shah, and to his cabinet were quite the opposite from the position noted in his diary. The fact that Carter chose that one diary entry to essentially carve his own history of the AWACS affair may be attributed to the proximity of the Iranian revolution at the time of writing (1982) and Carter's desire to give the appearance that he had maintained objectivity in his dealings with the Shah. However, the historical record shows this account to be less than accurate, and indicates Carter's own dis-ease with the choices he had to reluctantly make in this case.

Further adding to the discrepancies found in Carter's personal account, he prefaced the decision to approve the AWACS sale in the following way:

I was attempting to reduce the sale of offensive weapons throughout the world, but it was not possible to make excessively abrupt changes in current practices, because of the contracts already in existence. ${ }^{82}$

This statement is interesting in two ways: Firstly, he does not refer to the AWACS as a defensive weapon. Yet, this was a central defence of the sale to Congress despite the spurious nature of that claim. Presumably this had become a frail position to remain insistent on. Secondly, there were no contracts in existence in any sense for an Iranian purchase of the AWACS prior to Carter's offer in mid 1977. The AWACS was not ready for sale until 1977. Ford had purposefully deferred any foreign sales of the AWACS pending that readiness. With these points in mind, Carter's recollection of the AWACS affair is frankly strange. And, it goes to the heart of the quandary Carter found himself in with Iran - where the wider needs of American security placed him at odds with his personal preferences.

Whilst Carter had come to office with apparently genuine designs for arms control, the Iranian experience demonstrated the necessity for pragmatism and flexibility over idealism. As the U.S. Ambassador to Iran, William Sullivan,

\footnotetext{
81 Jimmy Carter, Keeping Faith: Memoirs of a President (London: Collins, 1982), pp. 434435.

82 Jimmy Carter, Keeping Faith, p. 435.
} 
cautioned during the raging Congressional debates over the AWACS, 'a great deal more than the export of airplanes' was involved.83 It is also notable that the opposition to the sale in Congress did not dwell primarily on attacking the clear contradictions in Carter's arms policies to score a political victory. Instead the Congressional discourse on the AWACS sale consistently focused on issues of proportionality, necessity, and security. Congress put genuine revisionism in U.S. arms policy at the forefront of its concerns - consolidating a clear trend that was in evidence throughout the mid-1970s. The fact that a major arms sale to Iran was the point at which a line was finally drawn in Washington is not surprising. What is perhaps surprising is that Carter and the Congress were on opposing sides of that line.

\section{Conclusion}

The AWACS episode, when viewed in its full detail within the context of U.S.-Iran arms policies, serves as something of a missing link in establishing how an arms control and human rights wielding president spent the end of his first year in office in Tehran toasting an autocrat with a dubious human rights record who was also America's largest arms purchaser. By maintaining, and expanding, the arms relationship with the Shah via the sale of the AWACS, Carter's personal and political experience exemplifies the lack of alternatives that existed for U.S. regional policy in the Persian Gulf in the late 1970s. After thirty years of investment and political winnowing, America's regional options had become heavily leveraged on the Shah's Iran, and more specifically on the arms relationship at the centre of diplomatic affairs.

When faced with the decision to sell, or not to sell, the AWACS to Iran, Carter faced an early test of will that resulted in him throwing his weight behind the spirit of the arms sale regime that was already established by the Nixon/Ford administrations rather than effect a notable change in U.S. policy. The fact that it took just a few months in mid 1977 for Carter to make that transition is testament to the binding that the Cold War placed on U.S. presidents in general. More specifically, the contradictory accounts of the AWACS episode found in the declassified record and in Carter's public accounts of events offer a new insight into Carter's personal plight as his ideals met the full force of reality through the course of the gruelling battle the administration had with Congress over the AWACS sale.

83 Telegram from Sullivan to Vance, 14 July 1977. JCL. RAC: NLC-16-40-3-23-2. 
Stephen McGlinchey is Senior Lecturer of International Relations at the University of the West of England, and Editor-in-Chief of E-International Relations.

Robert W. Murray is the Vice-President, Research at the Frontier Centre for Public Policy, an Adjunct Professor of Political Science at the University of Alberta, a Senior Fellow of Security and Defence Policy at the Atlantic Institute for Market Studies, and a Research Fellow at the University of Alberta's European Union Centre of Excellence. 